\title{
Trends of seed production, varietal scenario and future prospects in barley
}

\author{
Vishnu Kumar*, Lokendra Kumar and Ajit Singh Kharub \\ ICAR-Indian Institute of Wheat and Barley Research, Karnal, Haryana, India
}

Article history: Received: 24-02-2017, Revised : 08-03-2017, Accepted: 15-05-2017

Citation: Kumar V, L Kumar and AS Kharub. 2017. Trends of seed production, varietal scenario and future prospects in barley. Journal of Wheat Research 9(1): 64-67. doi.org/10.25174/2249-4065/2017/70102

\section{*Corresponding author email: vishnupbg@gmail.com}

(C) Society for Advancement of Wheat and Barley Research

Agriculture is one of the prime sectors in Indian economy and more than 58 per cent of the Indian population depends upon agriculture for their livelihood. However, with this quantum of population dependency, agriculture contributions were $13.9 \%$ during 2013-14, while compared with industry $(26.1 \%)$ and service $(59.9 \%)$ sectors, respectively (Chauhan et al., 2016). Seed is the most crucial input in agriculture to deliver technological interventions for enhancing crop production and ensuring livelihood security. The success of other factors is greatly dependent upon quality seed for a good harvest. Seed being a key factor for higher productivity, its production, supply and quality aspects are always prime concern for sustainable growth and achieving food security (Manjunatha et al., 2013). For yield maximization and enhancing net profit in barley like other cereals, quality seed production and availability is the first and utmost requirement for long term gain realization. The seed indents and supply are integral parts for the higher productivity for any crop, therefore the presented study was undertaken to analyse the recent barley breeder seed production trends of indented varieties for future prospects.

Barley is a primitive, sacred and one of the first domesticated cereals, which is also known as crop of resource poor small and marginal farmers (Kumar et al., 2013; Pasam et al., 2012). Barley is a model crop, which is adapted for harsh climates especially drought, salinity and other abiotic stresses (Baik and Ullrich, 2008; Nevo and Chen, 2010). Barley is one of the staple food resources altogether with other cereals i.e. rice, wheat and maize and contribute towards world wide energy intake in human diet (Brog et al., 2009). It ranked fourth after maize, rice and wheat with $144.33 \mathrm{mt}$ production, during 2014 globally (FAOSTAT, 2016; Kumar et al., 2015). Barley is a key crop among dry land cereals and grown over 100 countries mainly with dry agro-ecological conditions for food and feed purposes. Apart from food and feed, barley is also an industrial crop for brewing and malting due to its husk, enzymatic activities and beta-glucan. Due to low water and nutrient requirement, early maturity and malt based industries, barley is also preferred Rabi, crop in areas with scanty rainfall and as well as high input regions of India i.e. Rajasthan, Uttarakhand, Himachal Pradesh and Haryana, Punjab, Uttar Pradesh, Madhya Pradesh etc.). Barley also serves as good dual purposes cereal for green fodder followed by good grain harvest due to its early vigour, foliage growth, regeneration capacity and nutritive values (Verma et al., 2016).

The last 10 years (2005-06 to 2014-15) breeder seed allocation and production data are presented in table 1 and Fig. 1. The perusal of data indicated that from 200506 to 2009-10 the indents were increased from $360.55 \mathrm{q}$ to 2464.50 q, respectively (Table 1 ).

Similarly, the production of indented varieties also exhibited an increase from 851.61 q to 3077.79 q from 2005-06 to 200809 , respectively. Whereas, during 2009-10 the production (3052.52 q) was slightly lower than the year 2008-09. After 2011-12, the barley seed indents and production, showed downward trends from 2012-13 and 2013-14. This decline was observed due to the lower indents 
were placed by Rajasthan and Uttar Pradesh states. Even 90 per cent lower seed indents were placed from Uttar Pradesh during 2012-13 and 2013-14, respectively. The lower seed replacement rate (SRR), decline in area under barley cultivation, rise in irrigation facilities, NFSM covered crop cultivation etc. may be the reasons for this seed indent decline. During 2013-14 and 2014$15,1782.64 \mathrm{q}$ and $1141.16 \mathrm{q}$ breeder seed was produced against the allocation of 843.10 and 1111.75 q for 38 and 39 varieties, respectively (Anonymous, 2014; 2015). After analysis of past 10 years data it was observed that every year surplus seed was produced against the indented quantity, except the year 2012-13. The reason for this declined production was due to the breeder seed demand was curtailed in Rajasthan state by the indenting agency for major indented varieties i.e. RD 2035, RD 2052, RD 2552 etc., after placing higher indents.

Table 1. Past ten years barley breeder seed allocation and production trends

\begin{tabular}{cccc}
\hline Year & $\begin{array}{c}\text { Allocation } \\
(\mathrm{q})\end{array}$ & $\begin{array}{c}\text { Production } \\
(\mathrm{q})\end{array}$ & $\begin{array}{c}\text { No. of variet- } \\
\text { ies }\end{array}$ \\
\hline $2005-06$ & 360.55 & 851.61 & 22 \\
$2006-07$ & 1339.05 & 1915.50 & 22 \\
$2007-08$ & 1688.65 & 2316.83 & 35 \\
$2008-09$ & 2040.75 & 3077.79 & 29 \\
$2009-10$ & 2464.50 & 3052.52 & 30 \\
$2010-11$ & 1777.70 & 2912.18 & 28 \\
$2011-12$ & 1841.60 & 1905.80 & 28 \\
$2012-13$ & 1029.20 & 698.25 & 27 \\
$2013-14$ & 843.10 & 1782.64 & 38 \\
$2014-15$ & 1111.75 & 1141.16 & 39 \\
\hline
\end{tabular}

The consolidated breeder seed indent of $862.45 \mathrm{q}$ was received for ten states (Rajasthan, Uttar Pradesh, Uttarakhand, Haryana, Madhya Pradesh, Punjab, J\&K, Sikkim, Jharkhand and Himachal Pradesh), two public sector corporations (State Farm Corporation of India and National Seeds Corporation) and private agencies during 2013-14. The major proportion of the breeder seed indent was from SAI (328.25 q) followed by Rajasthan state (312q), State Farm Corporation of India, New Delhi (59 q), Madhya Pradesh (40 q) etc. A total breeder seed for production of $843.10 \mathrm{q}$ for 38 varieties was allocated for production at 10 seed producing centres over seven states. A net production of $1782.64 \mathrm{q}$ breeder seed against allocated varieties was reported, which was surplus (939.54 q) in comparison to the allocated quantity. The maximum production was observed for the variety
The number of indented barley varieties ranged from 22 to 39 from 2005-06 to 2014-15. During 2012-13, allocation was made for 1029.20 q breeder seed of 27 varieties, which included requirement of seven states (Rajasthan, Uttar Pradesh, Uttarakhand, Haryana, Madhya Pradesh, Punjab and Himachal Pradesh), two public sector corporations (State Farm Corporation of India and National Seeds Corporation) and private agencies. The major proportion of the breeder seed indent was from Rajasthan state $(45.53 \%)$ followed by SAI (36.28 \%), State Farm Corporation of India, New Delhi (7.28 \%), Uttar Pradesh (3.06 \%) etc. A net production of $698.25 \mathrm{q}$ breeder seed of all the allocated varieties was reported, which was deficit (330.95 q) in comparison to the allocated quantity. This deficit seed production was mainly due to SKRAU, Bikaner centre curtailed breeder seed production programme for the major indented varieties viz. RD 2035, RD 2052, RD 2503, RD 2552 and RD 2668 after receiving communication from the indenting agency i.e. Rajasthan State Seed Corporation Limited (RSSCL). The maximum production was observed for the variety $\mathrm{RD}$ 2035 (125 q) followed by RD 2715 (100 q), RD 2592 (90 q), DWRUB 52 (76.80 q), BH 393 (60 q), RD 2660 (55 q), BH 902 (50 q), PL 426 (50 q), DWRB 73 (40 q), DWRUB $64(64 \mathrm{q})$ etc.

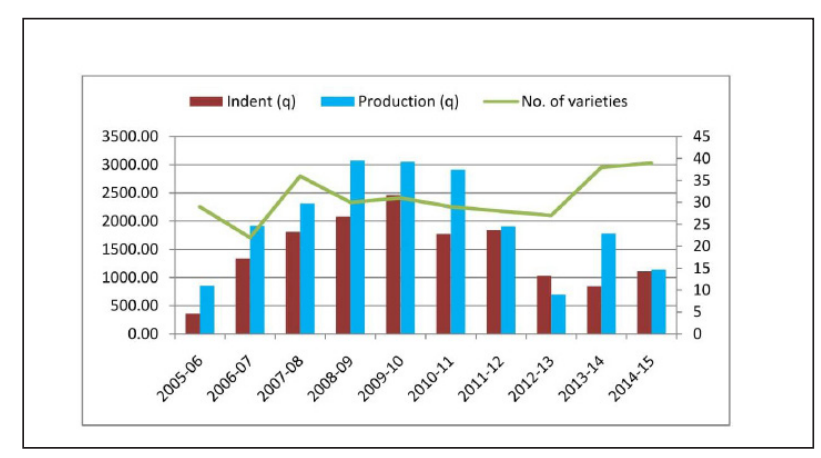

Fig. 1 Barley breeder seed indent and production trends (2005-06 to 2014-15)

RD 2552 (370 q) followed by RD 2035 (307 q), RD 2715 (224 q), RD 2660 (180 q), RD 2592 (100 q), PL 426 (81 q), RD 2052 (80 q), BH 393 (60 q), DWRUB 52 (59.67 q) etc. During 2014-15, an indent of 1114.45 q breeder seed of 41 varieties was received from nine states viz. Haryana, Himachal Pradesh, Madhya Pradesh, Meghalaya, Punjab, Rajasthan, Sikkim, Uttarakhand and Uttar Pradesh and National Seeds Corporation and Seed Association of India. The major portion of the indent was given by SAI (36.02 \%) followed by Rajasthan (31.59 \%), Uttar Pradesh (17.15\%), NSC (7.45\%) and Madhya Pradesh (5.65\%). 
A total of 1111.75 q breeder seed of 39 varieties was allocated to 12 producing centres spread over seven states. The highest indent was placed for the variety RD 2660 (238.0 q) followed by DWRUB 52 (105.0 q) and PL 426 (95.65 q), while the old varieties namely Dolma (0.30 q), HBL 87 $(0.40 \mathrm{q})$ and $\mathrm{BH} 75(0.40 \mathrm{q})$ were indented in very less quantities.

Due to adverse climatic conditions especially during crop maturity (untimely heavy rainfall and hailstorms), a deficit seed production was reported in some of the varieties. On the other hand, surplus production was also reported in some varieties viz. PL 426 (41.50 q), RD 2052 (41.90 q), RD 2552 (57.20 q), RD 2592 (16.0 q), RD 2624 (11.2 q), RD 2715 (23.0 q), RD 2786 (60.0 q), HUB 113 (36.8 q), NDB 940 (11.8 q) etc. For last three years (2012-13 to 2014-15) major indented varieties are presented in table 2. The data of table 2 depicted that the considered varieties occupied $86.88,83.48$ and 91.10 per cents of the total indent during last three years, respectively. Whereas, these varieties also contributed 89.12, 89.18 and 87.96 per cents of the total production from 2012-13 to 2014-15, respectively. From the major varieties it was exhibited that the few varieties viz. PL 426, RD 2052 and RD 2035 were released prior to 2000, while most of the indented varieties are modern adaptable high yielding varieties. Out of these above mentioned varieties, the indents for RD 2052 and RD 2035 have been decreased, while for PL 426 the indent trend was stable. It was apparent that the newly released varieties viz. BH 946 (NWPZ), DWRB 91 (NWPZ), HUB 113 (NEPZ) and RD 2786 (CZ) were also indented and certainly replaced old varieties. In general, the indents for the varieties viz. BH 393, DWRUB 52, PL 426, RD 2035 , RD 2592, RD 2660 and RD 2715 were higher during 2012-13 to 2014-15.

Table 2. Three years breeder seed indents and production of major varieties (2012-13 to 2014-15)

\begin{tabular}{|c|c|c|c|c|c|c|c|c|c|c|}
\hline \multirow[t]{2}{*}{ Varieties } & \multirow[t]{2}{*}{ Year } & \multirow{2}{*}{$\begin{array}{l}\text { Production } \\
\text { zone/state }\end{array}$} & \multirow{2}{*}{$\begin{array}{l}\text { Use } \\
\text { type }\end{array}$} & \multicolumn{2}{|c|}{ 2012-13 } & \multicolumn{2}{|c|}{ 2013-14 } & \multicolumn{2}{|c|}{ 2014-15 } & \multirow{2}{*}{$\begin{array}{c}\% \text { change } \\
\text { in indent } \\
\text { over } 2012 \\
13 \text { and } \\
2014-15\end{array}$} \\
\hline & & & & $\begin{array}{c}\text { Indent } \\
\text { (q) }\end{array}$ & $\begin{array}{l}\text { Produc- } \\
\text { tion (q) }\end{array}$ & $\begin{array}{l}\text { Indent } \\
\text { (q) }\end{array}$ & $\begin{array}{l}\text { Produc- } \\
\text { tion }(\mathrm{q})\end{array}$ & $\begin{array}{l}\text { Indent } \\
\text { (q) }\end{array}$ & $\begin{array}{l}\text { Produc- } \\
\text { tion }(q)\end{array}$ & \\
\hline BH 393 & 2002 & Haryana & Feed & 59.50 & 60.00 & 57.40 & 60.00 & 62.70 & 63.00 & 5.4 \\
\hline BH 902 & 2010 & NWPZ & Feed & 49.95 & 50.00 & 26.30 & 27.00 & 23.20 & 24.00 & -53.6 \\
\hline ВН 946 & 2014 & NWPZ & Feed & - & - & - & - & 52.80 & 52.80 & - \\
\hline DWRUB 52 & 2007 & NWPZ & Malt & 76.80 & 83.75 & 55.00 & 59.67 & 105.00 & 59.56 & 36.7 \\
\hline DWRB 91 & 2013 & NWPZ & Malt & - & - & 6.35 & 7.90 & 29.40 & 23.35 & - \\
\hline HUB113 & 2014 & NEPZ & Feed & - & - & - & - & 23.20 & 60.00 & - \\
\hline JB 58 & 2005 & MP & Feed & 6.70 & 8.50 & 17.00 & 56.24 & 41.00 & 32.40 & 511.9 \\
\hline NDB 943 & 2009 & Uttar Pradesh & Feed & 9.00 & - & 11.70 & 12.00 & 48.20 & 17.50 & 435.6 \\
\hline NDB 1173 & 2005 & NWPZ/NEPZ & Feed & 9.00 & - & 7.20 & 22.00 & 30.20 & 27.00 & 235.6 \\
\hline PL 426 & 1996 & Punjab & Feed & 88.15 & 50.00 & 80.75 & 81.00 & 95.65 & 137.15 & 8.5 \\
\hline RD 2035 & 1994 & NWPZ & Feed & 176.40 & 125.00 & 76.90 & 307.00 & 89.60 & 93.00 & -49.2 \\
\hline RD 2052 & 1991 & Rajasthan & Feed & 70.00 & - & 32.90 & 80.00 & 34.10 & 78.00 & -51.3 \\
\hline RD 2552 & 2000 & NWPZ/NEPZ & Feed & 111.70 & - & 8.80 & 370.00 & 2.80 & 60.00 & -97.5 \\
\hline RD 2592 & 2004 & Rajasthan & Feed & 75.00 & 90.00 & 10.00 & 100.00 & 20.00 & 36.00 & -73.3 \\
\hline RD 2660 & 2006 & NWPZ & Feed & 65.00 & 55.00 & 110.00 & 180.00 & 238.00 & 40.00 & 266.2 \\
\hline RD 2715 & 2009 & $\mathrm{CZ}$ & Feed & 97.00 & 100.00 & 192.50 & 224.00 & 67.00 & 90.00 & -30.9 \\
\hline RD 2786 & 2013 & $\mathrm{CZ}$ & Feed & - & - & 11.00 & 3.00 & 50.00 & 110.00 & - \\
\hline \multicolumn{4}{|c|}{ Per cent of total indent/production } & 86.88 & 89.12 & 83.48 & 89.18 & 91.10 & 87.96 & \\
\hline
\end{tabular}

After considering past ten years indent and production trends, it was observed that the seed indents during 2014-15 were three folds higher than 2005-06, while the production was increased by 34 per cent over 2005-06, respectively. During 2014-15, the placed indents were higher of 7.42 and 24.16 per cents over the previous years i.e. 2012-13 and 2013-14, respectively. The number of indented varieties ranged from 22 to 39 in barley breeder seed chain. On the basis of last three years, it was depicted that the seed indents for six-row feed barley varieties namely RD2660 and JB58 were increased tremendously i.e. two and five times, respectively. Similarly, the indents of salinity/alkalinity and hulless varieties namely NDB1173 and NDB943 were also increased two and four times, respectively. An increase of 36.7 per cent was also exhibited for two-row malt barley variety 
DWRUB 52, whereas, another malt barley variety DWRB 91 also became popular during 2014-15 and 2015-16 and indented in higher quantities.

The rainfed barley variety RD 2660 showed increase during 2012-13 (65.00 q), 2013-14 (110.00 q) and 2014-15 $(238.00 \mathrm{q})$, respectively. It is anticipated that in NWPZ, in future newly released malt barley varieties i.e. DWRB 92 and DWRB 101 (both timely sown) and DWRB 91(late sown) will find still higher places in indent due to their better malting quality and raw material demand of brewing and malting industries.It is also expected that due to low water availability in the drier regions with shortage of green fodder the dual purpose variety RD 2715 would also be demanded in higher quantities. In near future, the newly released high yielding and disease tolerant varieties i.e. BH 902, BH 946, BH 959, BHS 400, DWRB 101, HUB 113, RD 2849 etc.will find higher places in indents and will ensure higher productivity and industrial demand.

\section{Acknowledgement}

Authors are thankful to all the barley cooperating centres for honouring indents and seed production and all of the associated scientists with the barley breeder seed production activities.

\section{References}

1. Anonymous. 2014. Progress Report, P. 327. All India Coordinated Wheat and Barley Improvement Project 2013-14. Barley Network. DWR, Karnal.

2. Anonymous. 2015. Progress Report, P. 275. All India Coordinated Wheat and Barley Improvement Project 2014-15. Barley Network. ICAR-IIWBR, Karnal.

3. Baik BK and SE Ullrich. 2008. Barley for food: characteristics, improvement, and renewed interest. Journal of Cereal Science 48:233-242.

4. Borg S, H Brinch-Pedersen, B Tauris and PB Holm. 2009. Iron transport, deposition and bio-availability in the wheat and barley grain. Plant and Soil 325:1524 .
5. Chauhan JS, SR Prasad, S Pal, PR Choudhury and KU Bhaskar. 2016. Seed production of field crops in India: Quality assurance, status, impact and way forward. Indian Journal of Agricultural Sciences 86: $563-579$.

6. FAOSTAT. 2016. FAOSTAT. Food and Agriculture Organization (FAO) of the United Nations, Rome, Italy. Available at http://faostat3.fao.org (Accessed March 2016).

7. Kumar V, R Kumar, RPS Verma, AVerma and I Sharma. 2013. Recent trends in breeder seed production of barley ( $H$. vulgare L.) in India. Indian Journal of Agricultural Sciences 83: 576-578.

8. Kumar V, RPS Verma, SR Vishwakarma, D Kumar, AS Kharub and I Sharma. 2015. Characterization for DUS descriptors and environmental interaction studies for grain protein and starch content $(H$. vulgare L.). SABRAO Journal 47: 260-267.

9. Manjunatha BL, DUM Rao and MB Dastagiri. 2013. Trends in seed production growth drivers and present market status of Indian seed industry: An analytical study. Indian Journal of Agricultural Sciences 83: 315-320.

10. Nevo E and G Chen. 2010. Drought and salt tolerances in wild relatives for wheat and barley improvement. Plant, cell and environment 33:670-685.

11. Pasam RK, R Sharma, M Malosetti, FA Eeuwijk, G Haseneyer, B Kilian and A Graner. 2012. Genomewide association studies for agronomical traits in a world-wide spring barley collection. BMC plant Biology 27:12-16.

12. Verma RPS, AS Kharub, J Singh, V Kumar, I Sharma and AVerma. 2016. AMMI model to analyse G x E for dual purpose barley in multi-environments trials. Agricultural Science Digest 36: 9-16. 